\title{
Nymphal development of Podisus nigrispinus (Heteroptera, Pentatomidae) preying on larvae of Anticarsia gemmatalis (Lepidoptera, Noctuidae) fed with resistant and susceptible soybeans
}

\author{
Fausto da Costa Matos Neto ${ }^{1}$ \\ José Cola Zanuncio ${ }^{2}$ \\ Ivan $\mathrm{Cruz}^{3}$ \\ Jorge Brás Torres ${ }^{4}$
}

\begin{abstract}
Nymphal development of the predator Podisus nigrispinus (Dallas) fed with a susceptible (UFV 16) or an insect resistant soybean genotype (IAC 17) and with larvae of the prey Anticarsia gemmatalis Hübner (Lepidoptera, Noctuidae) reared on these genotypes, was evaluated. Survival and duration of each instar and of total nymphal stage, besides weight of nymphs at the beginning of each instar and of adults of $P$. nigrispinus soon after emergence, were also evaluated. Nymphal survival of this predator was similar with both genotypes $(64.41 \%$ for the UFV 16 and $72.88 \%$ for the IAC 17$)$. Duration of second and fourth instars for nymphs that originated females, of fourth instar for those that originated males, of the nymphal period for males (20.21 and 17.94 days) and females (19.76 and 18.19 days) was longer on the IAC 17 than on the UFV 16. Weight of third instar nymphs $(3.12 \mathrm{mg}$ and $2.42 \mathrm{mg}$ ) for those that originated males and of fifth instar $(26.20$ $\mathrm{mg}$ and $23.86 \mathrm{mg}$ ) for those that originated females and female weight after emergence $(65.76 \mathrm{mg}$ and $58.68 \mathrm{mg})$ was lower with the IAC 17 than with the UFV 16. Sex ratio of P. nigrispinus was not affected by the resistant soybean IAC 17.
\end{abstract}

KeYworDs. Asopinae; biological control; Heteroptera; Glycine max; tri-trophic interaction.

\section{INTRODUCTION}

Host plant resistance and biological control should be considered for management of Anticarsia gemmatalis Hübner (Lepidoptera, Noctuidae) due to adverse effects of chemical control (Zanuncio et al. 1998; Boethel 1999). Predators such as Podisus nigrispinus (Dallas) (Heteroptera, Pentatomidae) can play an important role in pest management programs of this pest in soybean crops (PANIZZI 1990). Even with good results of pest control with these methods, a higher efficiency could be expected with these methods combined. However, resistant plants can affect herbivores and also its natural enemies (PRICE et al. 1980).

ORR \& BoEthel (1986) verified that a resistant soybean genotype affected the development of Podisus maculiventris (Say) (Heteroptera, Pentatomidae) nymphs. Also, Rogers \&
SulLivan (1986) found that resistant soybean genotypes increased duration of the nymphal period and mortality of Geocoris punctipes (Say) (Heteroptera, Lygaeidae). G. punctipes fed with A. gemmatalis reared on artificial diet or on detached leaves of resistant or susceptible soybean genotypes had similar weight gain. However, weight gain of G. punctipes nymphs was higher when this predator was associated with non-detached leaves of the susceptible genotype soybean than with a resistant one (Rogers \& SULLIVAN 1987). These studies also showed that G. punctipes presented similar behavior when fed on soybean genotypes (resistant or susceptible) or on prey reared on these genotypes.

Feeding on soybean resistant plants can improve life history characteristics of predatory heteropterans (CRUM et al. 1998). On the other hand, indirect effects through an unsuitable prey, and direct effects from resistant plants secondary

1. Departamento de Fitotecnia, Universidade Federal de Viçosa. 36571-000 Viçosa-MG, Brazil. E-mail: fmatos@alunos.ufv.br

2. Departamento de Biologia Animal, Universidade Federal de Viçosa. 36571-000 Viçosa-MG, Brazil. E-mail: zanuncio@mail.ufv.br

3. Empresa Brasileira de Pesquisa Agropecuária (EMBRAPA). Caixa Postal 151, 35701-970 Sete Lagoas-MG, Brazil.

4. Departamento de Agronomia-Fitossanidade, Universidade Federal Rural de Pernanbuco. 52171-000 Recife-PE, Brazil. 
compounds can occur. Resistant genotypes can affect third trophic level and, hence the dynamic of arthropod communities. Therefore, the objective of this work was to study direct and indirect effects of the prey A. gemmatalis reared on a resistant (IAC 17) (LouRENÇÃo et al. 1997) or susceptible (UFV 16) soybean genotypes on the development of nymphs of the predatory bug $P$. nigrispinus.

\section{MATERIAL AND METHODS}

This research was conducted at the Laboratory of Biological Control of the Instituto de Biotecnologia Aplicada à Agricultura (BIOAGRO), Universidade Federal de Viçosa (UFV), in Viçosa, State of Minas Gerais, Brazil.

Five newly-emerged females of P. nigripinus were selected based on average population weight $(73.43 \mathrm{mg}$ ) of this predator. These females were mated in the fourth day after their emergence (ZANUNCIO et al. 1996/1997; MoHAGHEGH et al. 1998). Pairs of $P$. nigrispinus were maintained at the Laboratory of Biological Control, at room temperature and fed on larvae of Tenebrio molitor L. (Coleoptera, Tenebrionidae) (ZANuncio et al. 1994; Matos Neto et al. 1998) to obtain nymphs used in the experiment.

The colony of A. gemmatalis was maintained on leaflets of the soybean genotypes UFV 16 or IAC 17 (V4 to R4 growth stage) (SEDIYAma et al. 1989) obtained from plants in field plots.

Each experimental unit consisted of a Petri dish (15.0 x 1.5 $\mathrm{cm}$ ) for second and third instars and a transparent cage made with a plastic bottle (2 L) for fourth and fifth instar nymphs of P. nigrispinus (Assis JúNIOR et al. 1999). The bottom of these bottles were removed and it was placed over a plastic pot (500 $\mathrm{ml}$ ) with a soybean plant, previously cultivated in a greenhouse. A circular hole ( $4 \mathrm{~cm}$ diameter) in the upper part of these bottles was covered with a cotton screen. Distilled water was supplied by an anesthetic tube $(2 \mathrm{ml})$ fixed through a hole in the upper part of these bottles.

The experiment was initiated with second instar nymphs of P. nigrispinus with similar weight. Second and third instar nymphs were individualized inside Petri dishes (due to high mortality levels when they were maintained inside $2 \mathrm{~L}$ bottles based on previous studies) with a soybean leaflet, one $A$. gemmatalis larva (1.5 cm long) and distilled water (SAAVEDRA et al. 1997).

Nymphs of $P$. nigrispinus at the beginning of fourth instar were individualized in $2 \mathrm{~L}$ cages with a soybean plant in $\mathrm{V} 3$ or V4 stadium (SEDIYAma et al. 1989), one larva of A. gemmatalis (1.5 cm long) and distilled water according to two treatments: UFV 16 - one larva of $A$. gemmatalis reared on the UFV 16 soybean genotype and one detached soybean leaflet or plant of this genotype; and IAC 17 - one larva of A. gemmatalis reared on the IAC 17 soybean genotype and one detached soybean leaflet or plant of this genotype. Leaflets and dead larvae were replaced daily and soybean plants were changed every four days. Each treatment had 60 replications at $25 \pm 2{ }^{\circ} \mathrm{C}$, $71 \pm 7 \%$ relative humidity and photophase of 14 hours.
Duration of each instar and of total nymphal stage, mortality of nymphs, and weight of nymphs at molting day and adults at the day of emergence were evaluated. Mortality rate was evaluated for each instar independently of the sex. The results were submitted to the Bartlett and Lilliefors tests for certifying the assumptions for the analysis of variance. A non-parametric test of Wilcoxon at 5\% probability was performed due to heterocedasticity results.

\section{RESULTS}

Survival and Sex Ratio. Survival of second instar (Table I) was higher for nymphs reared on the resistant IAC 17 than with the susceptible UFV 16 soybean genotype. No significant differences on survival were observed during the older instars and for total nymphal period. Mortality of nymphs of $P$. nigrispinus associated to the UFV 16 decreased with the development of this insect. On the other hand, this mortality was similar during all instars with the IAC 17 soybean genotype, except for the third. Sex ratio of $P$. nigrispinus was not affected by the soybean genotype ( 0.55 with the susceptible and 0.67 with the resistant genotype) (Table I).

Table I - Survival of nymphs and sex ratio of adults (mean \pm SE) of the predator Podisus nigrispinus (Heteroptera, Pentatomidae) with a plant of the soybean genotype UFV 16, susceptible, or the IAC 17, resistant, to insects and larvae of Anticarsia gemmatalis (Lepidoptera, Noctuidae) reared on leaflets of these genotypes at $25 \pm 2^{\circ} \mathrm{C}, 71 \pm 7 \%$ relative humidity and photophase of 14 hours.

\begin{tabular}{|c|c|c|}
\hline Instar & $\begin{array}{c}\text { UFV } 16 \\
(\%)\end{array}$ & $\begin{array}{c}\text { IAC } 17 \\
(\%)\end{array}$ \\
\hline Nymph II & $83.05 \pm 4.93 b$ & $93.33 \pm 3.25 \mathrm{a}$ \\
\hline Nymph III & $85.71 \pm 5.05 \mathrm{a}$ & $89.09 \pm 4.24 \mathrm{a}$ \\
\hline Nymph IV & $92.86 \pm 4.02 \mathrm{a}$ & $93.88 \pm 3.46 \mathrm{a}$ \\
\hline Nymph V & $97.44 \pm 2.56 \mathrm{a}$ & $93.48 \pm 3.38 \mathrm{a}$ \\
\hline Nymphal Stage & $64.41 \pm 6.29 \mathrm{a}$ & $72.88 \pm 5.84 \mathrm{a}$ \\
\hline Sex Ratio & $0.55 \pm 0.08 \mathrm{a}$ & $0.67 \pm 0.07 \mathrm{a}$ \\
\hline
\end{tabular}

Means followed by the same letter between columns are not significantly different by Wilcoxon test $(\mathrm{p}<0.05)$.

Duration. Duration of second instar for P. nigispinus nymphs associated with the IAC 17 genotype was longer for those that originated females, but this was similar for those that originated males (Table II). Significant differences were not found between treatments, for third and fifth instar nymphs that originated males or females. Males and females of $P$. nigrispinus presented longer duration of fourth instar nymphs associated with the IAC 17 genotype. P. nigrispinus showed longer nymphal period when reared on the resistant soybean genotype. 
Table II - Duration (mean \pm SE) of instars and of the nymphal stage of the predator Podisus nigrispinus (Heteroptera, Pentatomidae) with a plant of the soybean genotype UFV 16, susceptible, or the IAC 17, resistant, to insects and larvae of Anticarsia gemmatalis (Lepidoptera, Noctuidae) fed with leaflets of these genotypes at $25 \pm 2^{\circ} \mathrm{C}, 71 \pm 7 \%$ relative humidity and photophase of 14 hours.

\begin{tabular}{|c|c|c|c|}
\hline Instar & Sex & $\begin{array}{l}\text { UFV } 16 \\
\text { (days) }\end{array}$ & $\begin{array}{l}\text { IAC } 17 \\
\text { (days) }\end{array}$ \\
\hline \multirow[t]{2}{*}{ II } & Females & $3.86 \pm 0.22 \mathrm{~b}$ & $4.38 \pm 0.21 \mathrm{a}$ \\
\hline & Males & $3.94 \pm 0.20 \mathrm{a}$ & $4.86 \pm 0.59 a$ \\
\hline \multirow[t]{2}{*}{ III } & Females & $4.10 \pm 0.21 \mathrm{a}$ & $4.17 \pm 0.19 a$ \\
\hline & Males & $4.29 \pm 0.29 a$ & $4.50 \pm 0.29 a$ \\
\hline \multirow[t]{2}{*}{ IV } & Females & $3.90 \pm 0.21 b$ & $4.66 \pm 0.25 \mathrm{a}$ \\
\hline & Males & $3.69 \pm 0.27 b$ & $4.46 \pm 0.39 a$ \\
\hline \multirow[t]{2}{*}{$\mathrm{V}$} & Females & $6.33 \pm 0.21 \mathrm{a}$ & $6.55 \pm 0.25 \mathrm{a}$ \\
\hline & Males & $5.81 \pm 0.14 \mathrm{a}$ & $6.46 \pm 0.45 a$ \\
\hline Nymphal & Females & $18.19 \pm 0.33 b$ & $19.76 \pm 0.51 \mathrm{a}$ \\
\hline Stage & Males & $17.94 \pm 0.62 b$ & $20.21 \pm 0.99 a$ \\
\hline
\end{tabular}

Means followed by the same letter between columns are not significantly different by Wilcoxon test $(\mathrm{p}<0.05)$.

Weight. Third and fourth instar $P$. nigrispinus nymphs that originated females presented similar weight (Table III), but these nymphs showed lower weight in the fifth instar with the resistant genotype. Furthermore, third instar nymphs that originated males presented lower weight when associated with the resis-

Table III - Weight (mean \pm SE) of nymphs and adults of the predator Podisus nigrispinus (Heteroptera, Pentatomidae) with a plant of the soybean genotype UFV 16, susceptible, or the IAC 17, resistant, to insects and larvae of Anticarsia gemmatalis (Lepidoptera, Noctuidae) reared on leaflets of these genotypes at $25 \pm 2^{\circ} \mathrm{C}, 71 \pm 7 \%$ relative humidity and photophase of 14 hours.

\begin{tabular}{llcc}
\hline Instar & Sex & $\begin{array}{c}\text { UFV 16 } \\
(\mathrm{mg})\end{array}$ & $\begin{array}{c}\text { IAC 17 } \\
(\mathrm{mg})\end{array}$ \\
\hline III & Females & $\begin{array}{c}3.12 \pm 0.20 \mathrm{a} \\
3.12 \pm 0.29 \mathrm{a}\end{array}$ & $\begin{array}{c}2.92 \pm 0.19 \mathrm{a} \\
\end{array}$ \\
& Males & & \\
& & & \\
IV & Females & $9.10 \pm 0.52 \mathrm{a}$ & $9.24 \pm 0.54 \mathrm{a}$ \\
& Males & $10.29 \pm 1.19 \mathrm{a}$ & $8.81 \pm 1.06 \mathrm{a}$ \\
& & & \\
V & Females & $26.20 \pm 1.23 \mathrm{a}$ & $23.86 \pm 0.91 \mathrm{~b}$ \\
& Machos & $22.77 \pm 1.49 \mathrm{a}$ & $21.61 \pm 1.43 \mathrm{a}$ \\
& & & \\
Adults & Females & $65.76 \pm 2.75 \mathrm{a}$ & $58.68 \pm 2.27 \mathrm{~b}$ \\
& Males & $43.65 \pm 1.98 \mathrm{a}$ & $40.43 \pm 1.78 \mathrm{a}$
\end{tabular}

Means followed by the same letter between columns are not significantly different by Wilcoxon test $(\mathrm{p}<0.05)$. tant genotype. This effect was not verified for fourth and fifth instar nymphs. The resistant genotype reduced weight of recently-emerged females but not of males.

\section{DISCUSSION}

Survival. Nymphal survival of $P$. nigrispinus was similar to that reported by TORRES et al. (1998) (74.75\%) for this predator and it also agrees with results observed for $P$. maculiventris by ORR \& BOETHEL (1986) which showed higher mortality of fifth instar nymphs with the resistant soybean genotype than with the susceptible one. Rogers \& SULLIVAN (1986) observed similar nymphal mortality of $G$. punctipes associated with the susceptible soybean genotype "Bragg" or with the insect resistant PI 229358, but nymphal mortality was higher with the insect resistant genotype PI 171451 than with the genotype Bragg. The soybean introduction PI's lines are reported to present natural resistance to chewing pests (BOETHEL 1999) as reported for the soybean variety IAC 17 (LOURENÇão et al. 1997). For this reason, the results found in this study are comparable to previous ones and produced similar effects on third trophic level to these observed for $G$. punctipes and $P$. maculiventris.

ROGERS \& SUlLIVAN (1987) found that detached leaflets of a resistant soybean genotype might not reflect similar effects on G. punctipes compared to attached leaflets. A similar situation could have occurred with survival of second and third instars nymphs and to a possible deleterious effect of the resistant genotype. However, results of the two other instars indicated that this effect (ROGERS \& SULLIVAN 1987) should not be generalized. Survival of second and third instars with detached leaflets was similar to that of fourth and fifth instars what might be due to an indirect effect on second and third instars of this predator feeding on prey reared on the resistant soybean genotype.

Sex ratio. Sex ratio of $P$. nigrispinus was not affected by feeding on $A$. gemmatalis reared on the resistant IAC 17 soybean genotype. This should be considered a normal situation because the sex is genetically determined. However, sex ratio can be affected due to a lower prey quality or to alelochemicals of resistant plant genotypes. This could have caused a higher female mortality of $P$. nigrispinus because they usually demand a higher food source. In this case they could receive higher quantity of possible toxic compounds from resistant soybean than males (Cohen 1984; De ClercQ \& DegheEle 1993; ZANUNCio et al. 1996).

Duration. Duration of nymphal period for males and females of $P$. nigrispinus was shorter than the 23.67 days found by SAAVEDRA et al. (1996). Longer duration of fourth instar was verified by ORR \& BOETHEL (1986) for $P$. maculiventris with the resistant soybean genotype PI 227687 cultivated in greenhouse. Fifth instar nymphs of this predator presented similar duration when fed with larvae of Manduca sexta (L.) (Lepidoptera, Sphingidae) reared on an artificial diet with different concentrations of the allelochemical rutin (STAMP et al. 1991). Nymphal duration of $G$. punctipes fed with $A$. gemmatalis larvae reared 
on a resistant soybean genotype was longer than with this prey reared on a susceptible genotype (Rogers \& SUlLIVAN 1986). Increasing duration of immature stages has been reported for other predators such as Hippodamia convergens Guerin (Coleoptera, Coccinelidae) fed on Schizaphis graminum (Rondani) (Homoptera, Aphididae) reared on resistant than on a susceptible sorghum genotypes (RICE \& WILDE 1989).

Weight. Lower weight of fifth instar nymphs that originated females showed a negative effect of the resistant IAC 17 on P. nigrispinus. Maximum development of reproductive organs especially of nymphs that will originate females occur during this instar what shows that these nymphs have higher nutritional demands. No effects of the resistant genotype during fifth instar on weight of nymphs that originated males was, possibly, due to their lower nutritional demands for development of reproductive organs of these insects.

Lower weight of females at emergence shows a deleterious effect of the IAC 17 genotype on $P$. nigrispinus. Negative effect of resistant genotypes on weight of predators has been reported by other authors. P. maculiventris females showed lower weight with a resistant than with a susceptible soybean variety (OrR \& Boethel 1986). Rogers \& Sullivan (1986) showed a reduction on weight gain of $G$. punctipes associated to the resistant genotype PI 171451 compared to the susceptible "Govan". Fifth instar P. maculiventris nymphs presented lower weight gain when fed on $M$. sexta caterpillars reared on artificial diet with higher rutin concentration but they originated males and females of similar weight (STAMP et al. 1991). This might have occurred because these nymphs were submitted to treatments only when they reached fifth instar.

\section{CONCLUSION}

Nymphal survival of $P$. nigrispinus was not affected by the resistant genotype IAC 17 but nymphal period of this predator was prolonged for individuals which originated males or females and weight of females was reduced. Therefore, the findings indicate that the impact of the resistant soybean genotype was not high enough to cause a significant mortality of $P$. nigrispinus nymphs. Longer duration of the nymphal phase with the resistant soybean genotype can result in lower number of generations and of individuals of $P$. nigrispinus. It should be considered that females with lower body weight have lower reproductive potential (EvANs 1982) what can affect the performance of this predator on field conditions.

Acknowledgements. To the Conselho Nacional de Desenvolvimento Científico e Tecnológico $(\mathrm{CNPq})$, to the Fundação de Amparo à Pesquisa do Estado de Minas Gerais (FAPEMIG) for grants.

\section{REFERENCES}

Assis Júnior, S. L.; J. C. Zanuncio; M. C. Picanço \& R. N. C. Guedes. 1999. Effects of the association of the predatory bug Supputius cincticeps (Stal, 1860) (Heteroptera: Pentatomidae: Asopinae) with Eucalyp- tus urophylla seedlings. Tropical Ecology 40(1):85-88.

Boethel, D. J. 1999. Assessment of soybean germplasm for multiple insect resistance, p.101-129. In: S. L. Clement \& S. S. QuisenberRY (eds.). Global plant genetic resources for insect-resistant crops. Boca Raton, CRC Press, xii +295 p.

Crum, D. A.; L. A. Weiser \& N. E. Stamp. 1998. Effects of prey scarcity and plant material as a dietary supplement on an insect predator. Oikos 81(3):549-557.

De ClercQ, P. \& D. Degheele. 1993. Quality assessment of the predatory bugs Podisus maculiventris (Say) and Podisus sagitta (Fab.) (Heteroptera: Pentatomidae) after prolonged rearing on a meatbased artificial diet. Biocontrol Science and Technology 3(1): 133-139.

Cohen, A. C. 1984. Food consumption, food utilization and metabolic rates of Geocoris punctipes (Het.: Lygaeidae) fed Heliothis virescens (Lep.: Noctuidae) eggs. Entomophaga 29(3):361-367.

Evans, E. W. 1982. Consequences of body size for fecundity in the predatory stinkbug, Podisus maculiventris (Hemiptera: Pentatomidae). Annals of the Entomological Society of America 75(4):418-420.

Lourenção, A. L.; M. A. C. Miranda; J. C. V. N. A. Pereira \& G. M. B. Ambrosano. 1997. Resistência de soja a insetos. X. Comportamento de cultivares e linhagens em relação a percevejos e desfolhadores. Anais da Sociedade Entomológica do Brasil 26(3):543-550.

Matos Neto, F. C.; J. C. Zanuncio; L. C. Freitas \& B. M. R. Gomes. 1998. Nymphal development of the predator Podisus rostralis (Heteroptera: Pentatomidae) fed with three alternative prey. Brenesia 49-50(31):71-77.

Mohaghegh, J.; P. De Clerce \& L. Tirry. 1998. Effects of maternal age and egg weight on development time and body weight of offspring of Podisus maculiventris (Heteroptera: Pentatomidae). Annals of the Entomological Society of America 91(3):315-322.

ORR, D. B. \& D. J. Boethel. 1986. Influence of plant antibiosis through four trophic levels. Oecologia 70(3):242-249.

Panizzi, A. R. 1990. Manejo integrado de pragas da soja no Brasil, p. 293321. In: P. Свосомо (ed.). Manejo integrado de pragas. São Paulo, Editora UNESP, vii $+358 \mathrm{p}$.

Price, P. W.; C. E. Bouton; P. Gross; B. A. McPheron; J. N. Thompson \& A. E. WEIs. 1980. Interactions among three trophic levels: influence of plants on interactions between insect herbivores and natural enemies. Annual Review of Ecology and Systematics 11:41-65.

Rice, M. E. \& G. E. WiLdE. 1989. Antibiosis effect of sorghum on the convergent lady beetle (Coleoptera: Coccinellidae), a third-trophic level predator of the greenbug (Homoptera: Aphididae). Journal of Economic Entomology 82(2):570-573.

Rogers, D. J. \& M. J. Sullivan. 1986. Nymphal performance of Geocoris punctipes (Hemiptera: Lygaeidae) on pest-resistant soybeans. Environmental Entomology 15(5):1032-1036.

Rogers, D. J. \& M. J. Sullivan. 1987. Growth of Geocoris punctipes (Hemiptera: Lygaeidae) on attached and detached leaves of pest resistant soybeans. Journal of Entomogical Science 22(3):282285.

SAavedra, J. L. D.; J. C. Zanuncio; T. V. Zanuncio \& G. P. Santos. 1996. Desarrollo ninfal de Podisus nigrispinus (Heteroptera: Pentatomidae) en alimentacion mixta de dieta artificial y larvas de Musca domestica (Diptera: Muscidae). Brenesia 45/46(3/1):177-182.

SaAvedra, J. L. D.; J. C. Zanuncio; T. V. Zanuncio \& R. N. C. Guedes. 1997. Prey capture ability of Podisus nigrispinus (Dallas) (Het., Pentatomidae) reared for successive generations on a meridic diet. Journal of Applied Entomology 121(4):327-330.

Sediyama, T.; M. G. Pereira; C. S. Sediyama \& J. L. L. Gomes. 1989. Cultura da soja - Parte II. Viçosa, Universidade Federal de Viçosa, vi +75 p.

Stamp, N. E.; T. ERskine \& C. J. Paradise. 1991. Effects of rutin-fed caterpillars on an invertebrate predator depend on temperature. Oecologia 88(2):289-295.

Torres, J. B.; J. C. Zanuncio \& H. N. Oliveira. 1998. Nymphal development and adult reproduction of the stinkbug predator Podisus nigrispinus (Heteroptera: Pentatomidae) under fluctuating temperatures. Journal of Applied Entomology 122(4):509-514.

Zanuncio, J. C.; J. B. Alves; T. V. Zanuncio \& J. F. Garcia. 1994. Hemipterous 
predators of eucalypt defoliator caterpillars. Forest Ecology and Management 65(1):65-73.

Zanuncio, T. V.; J. C. Zanuncio; J. L. D. SaAvedra \& E. D. Lopes. 1996. Desenvolvimento de Podisus nigrispinus (Dallas) (Heteroptera, Pentatomidae) com Zophobas confusa Gebien (Coleoptera, Tenebrionidae) comparado à duas outras presas alternativas. Revista Brasileira de Zoologia 13(1): 159-164.

Zanuncio, J. C.; J. L. D. SaAvedra; T. V. Zanuncio \& G. P. Santos. 1996/
1997. Incremento en el peso de ninfas y adultos de Podisus nigrispinus (Heteroptera: Pentatomidae) alimentados com dos tipos de larvas. Revista de Biologia Tropical 44/45(3/1):241-245.

Zanuncio, J. C.; V. C. Batalha; R. N. C. Guedes \& M. C. Picanço. 1998. Insecticide selectivity to Supputius cincticeps (Stal) (Het.: Pentatomidae) and its prey Spodoptera frugiperada (J.E. Smith) (Lep.: Noctuidae). Journal of Applied Entomology 122(3):457460 . 